\title{
VIRAL DISEASE AND LIPID PEROXIDATION IN CONDITIONS OF BIOTIC AND ABIOTIC STRESS OF SAMBUCUS NIGRA L. PLANTS
}

\author{
Taran Oksana ${ }^{1}$, Mishchenko Lidya ${ }^{2}$, Nesterova Nataliia ${ }^{1}$, Dunich Alina ${ }^{2}$ \\ ${ }^{1}$ National University of Life and Environmental Sciences of Ukraine, Kyiv, Ukraine \\ ${ }^{2}$ ESC «Institute of Biology and Medicine», Taras Shevchenko National University of Kyiv, Kyiv, Ukraine
}

Received 26. 6. 2017

Revised 29.6. 2017

Published 30.11.2017

For the first time in Ukraine, a virus disease of elderberry (Sambucus nigra L.) was found. Plants with symptoms of a viral infection were found in 2015-2016 in the Poltava region, in 2016 the same symptoms on elder plants were disfigured in the Kiev region. The symptoms of the disease and the morphological properties of the virus were studied. We found plants with chlorotic symptoms, mosaic and chain mail, plants rolling on the tops of leaves, and twisting the edges. In the leaves of infected plants, filamentous virions with a particle length of $650 \pm 50 \mathrm{~nm}$ were detected by the method of electron microscopy. Based on the scientific literature data, viruses that can infect elder plants in Ukraine are screened. The levels of lipid peroxidation in older plants under conditions of viral infection and heat stress were studied. It is shown that a viral infection significantly reduces the content of TBA-active products in elder plants. The content of malonic dialdehyde significantly increased under conditions of heat stress in plants with symptoms of viral infection. At the same time, the content of TBA-active products in the leaves of healthy plants was insignificant. This indicates a negative effect of viral infection on the antioxidant system of elder plants. Further studies are needed to establish the systematic position of the detected viral particles and to create diagnosticums for the detection of these viruses. It is also necessary to study the ecological links of viruses identified in elderberry.

Keywords: elderberry; Sambucus spp.; viral diseases; viruses; lipid peroxidation; malondialdehyde

\section{Introduction}

Plants of genus Sambucus L. have a number of potentially useful medicinal attributes including diuretic, diaphoretic, purgative and hemostatic properties. These effects must be due to the presence of chemical compounds with pharmacological activity. For instance, polyphenolic substances have been associated with antioxidant action (Kiselova et al., 2006; Ebrahimzadeh et al., 2014). The cyan colour of the ripe elder fruit is due to several anthocyanidins such as cyanidin-3-O-glucoside. This anthocyanidin is especially important since it has been found to inhibit the growth of cancer cells and tumor xenographts in immune-deficient mice (Ding et al., 2006). In addition, studies have shown the possibility of using elderberry to control and prevent hyperglycemia in dietary supplements that restore the normal metabolic environment, which reduces the long-term complications associated with diabetes. It has been found that the aqueous extract of elder has significantly increased the transport of 2-deoxy-glucose, glucose oxidation and glycogenesis of mouse abdominal muscles in the absence of insulin (Gray Alison et al., 2000). 
It is know that in addition to the general structural and enzymatic protein characteristics of plant species, Sambucus contains bioactive proteins like single- and two-chain lectins and ribosomeinactivating proteins (Girbes et al., 2004; Lapadula et al., 2013). The biological role of all these proteins is as yet unknown. The evidence suggests that they could be involved in the defense of the plant against predators and viruses or/and a nitrogen store, with an impact on the nutritional characteristics and food safety (Jiménez et al., 2015; Tejero et al., 2015).

Viral diseases of elderberry plants first described in 1925. A mosaic of Sambucus canadensis L. was identified in Pennsylvania, Florida and Wilkinson, the simptoms of disease were similar of disease to be caused by tobacco ringspot virus (Martin, 1925). Tomato ringspot virus and tabacco ring spot virus have been detected in native Sambucus in New York (Gilmer and Kelts, 1968; Hansen and StaceSmith, 1971). Most reports of elderberry infecting are about Cherry leaf roll virus and carlaviruses. Blueberry scorch virus (BISCV), Elderberry symptomless virus (EIBSV) and several other putative members of the genus Carlavirus (family Betaflexiviridae) have also been reported in elderberry (Van Lent et al., 1980; Ellis et al., 1992; Cavileer et al., 1994; Kalinowska et al., 2013). There is report about infecting of Sambucus canadensis plants by filamentous virus which similar on morphological features to carlaviruses (Jones, 1972). Subsequently, the virus was detected in the Netherlands and was named Elderberry virus A (Van Lent et al., 1980). Recent studies of elderberry samples (Sambucus spp.) from Missouri (USA) showed infecting of these plants with two different viruses, which also belong to the genus Carlavirus (Keller et al., 2015). Five novel carlaviruses tentatively named as Elderberry virus A-E (EIVA-EIVE, respectively) were discovered (Ho and Tzanetakis, 2014; Ho et al., 2016). Several viruses are known to cause detrimental symptoms in both American and European elderberry including members of the family Bromoviridae (Way, 1981), such as cucumber mosaic virus (CMV).

However, only in a few instances symptoms observed on diseased Sambucus plants were reported to be correlated with the virus isolated from them. Grbelja (1972) and Schmelzer (1966) proved that the vein clearing, chlorotic spots, rings and line pattern in Sambucus racemosa L. were caused by CLRV. Similar symptoms in Sambucus nigra L. were shown to be evoked by either CLRV (Grbelja, 1972; Jones, 1973), or TBRV (Schmelzer, 1966), and those in Sambucus nigra L.,Aurea' by GEV (Hansen and Stace-Smith, 1971). Tobacco ringspot virus was shown to be responsible for ringspotting, vein clearing and dark-green mottle in S. canadensis L., whereas TNV was proved to be the killing agent of apical buds and leaves of this Sambucus species (Van Lent et al., 1980).

In experiments with Sambucus pubens Michx. plants inoculated with the filamentous virus remained symptomless, whereas those inoculated with CLRV or with a mixture of CLRV and the filamentous virus exhibited concentric chlorotic rings, (ring) spots, line pattern and mosaic (Van Lent et al., 1980).

Thus, there is a lot of data on infecting Sambucus plants in the world. There are separate reports about the study of viruses, which infecting elderberry in Eastern Europe, particularly, in Poland (Pospieszny et al., 2004; Kalinowska et al., 2013), Croatia (Grbelja, 1972), Hungary (Horvath et al., 1974). Dissemination of viral diseases of elderberry in Ukraine has not been investigated until now.

There is also little information on the effect of viral infection on antioxidant status of elderberry plants, particularly on the activity of lipid peroxidation (LP). As viral infection is a stress factor comparatively to the plant, the activity of LP in the context of viral infection should change some way. Free radical oxidation disrupts the structure of many molecules such as proteins, amino acids, activates proteolytic enzymes in the cell, which hydrolyze damaged proteins. Active forms of oxygen easily break the structure of DNA. The main substrate of LP is polyunsaturated fatty acid chains, which are part of cell membranes, also lipoproteins. Particularly, the activity of the LP increases with the combined 
action of stress factors, for example, the influence of the pathogen and increased temperatures. Such stress conditions can cause a displacement in the balance between LP and antioxidant activity in cell, which in turn leads to accumulation of substances that degrade the quality of plant material and reduce its therapeutic properties. Therefore, the purpose of our study was to detect viruses, that infect elderberry on the territory of Ukraine and to determine the influence of viral infection on activity of LP.

\section{Materials and methodology}

For diagnostics of viruses in the plants applied the methods of visual diagnostics and transmission electronic microscopy (EM). Contrasting has been made with $2 \%$ solution of phosphorus-tungstic acid. Virions are investigated using electron microscope JEM 1230 (JEOL, Japan). The level of lipid peroxidation in the leaf tissue was measured in terms of malondialdehyde (MDA, a product of lipid peroxidation) content determined by the thiobarbituric acid (TBA) reaction (Jambunathan, 2010). A $0.25 \mathrm{~g}$ leaf sample was homogenized in $5 \mathrm{ml} 0.1 \%$ TCA. The homogenate was centrifuged at $10000 \mathrm{~g}$ for $5 \mathrm{~min}$. To $1 \mathrm{ml}$ aliquot of the supernatant $4 \mathrm{ml} 20 \%$ TCA containing $0.5 \%$ TBA were added. The mixture was heated at $95{ }^{\circ} \mathrm{C}$ for $30 \mathrm{~min}$ and then quickly cooled in an ice-bath. After centrifuging at $10000 \mathrm{~g}$ for $10 \mathrm{~min}$ the absorbance of the supernatant at $532 \mathrm{~nm}$ was read and the value for the non-specific absorption at $600 \mathrm{~nm}$ was subtracted. The concentration of MDA was calculated using its extinction coefficient of $155 \mathrm{mM} / \mathrm{cm}$. To create the heat stress effect, the leaves were placed for $1 \mathrm{~h}$ in a thermostat at a temperature of $35^{\circ} \mathrm{C}$. The control plants had no symptoms of viral infection and were exposed at room temperature. The extinction values (the optical density) of the samples were processed by statistical analysis of Student's criterion, quoted by Atramentova and Utevskaya (2008). The confidential intervals were at a significance rate of $P \leq 0.05$ of Student's.

\section{Results and discussion}

Under observations of wild elderberry plants in Poltava (2015-2016) and Kyiv (2016) regions we detected plants with chlorotic symptoms, mosaic and ringspotting (Figure 1). As well, plants rolling of leaf tops and twisting up the edges of the leaves were identified (Mishchenko et al., 2016).
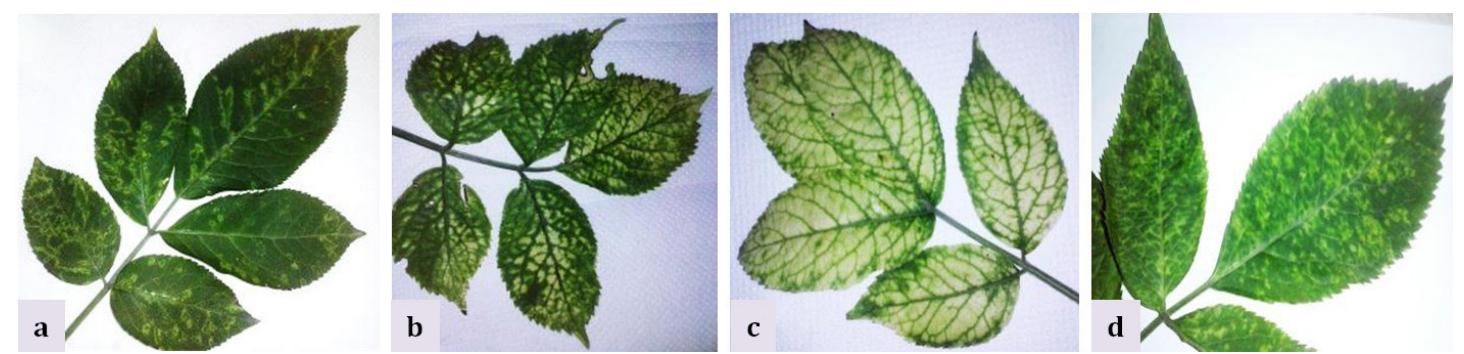

Figure 1 Symptoms of viral infection on Sambucus nigra L. plants a - ringspotting, b, c - chlorotic foliage symptoms; $d$ - mosaic

Number of affected plants accounted for over $20 \%$ of surveyed wild elderberry. It should be noted that analysis of world scientific literature on elderberry viruses showed that the most common symptom is chlorotic mottling ('blotching') and induced by many viruses. Filamentous virions $650 \pm 50 \times 12 \mathrm{~nm}$ were found in the elderberry leaves conducting the transmission electron microscopy method (Figure 2). Viral particles are morphologically similar to viruses of the genus Carlavirus (family 
Betaflexiviridae). It is known that the viruses that infect elder plants belong to this genus (Ho and Tzanetakis, 2014; Ho et al., 2016), but for final clarification it is necessary to carry out immunological and other molecular studies.

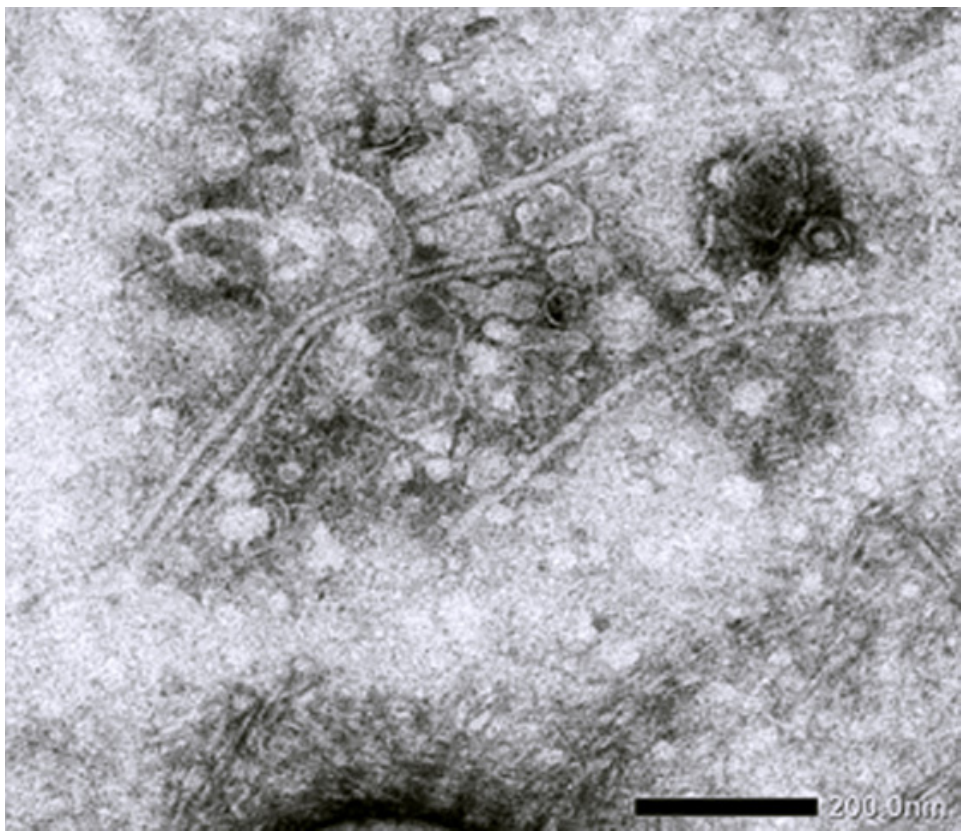

Figure 2 Electronogram of sap preparations from plants Sambucus nigra L. (bar $=200 \mathrm{~nm}$ )

Studies have shown that in plants without symptoms of viral infection with increasing temperature, changes in MDA content occur slightly (Figure 3).

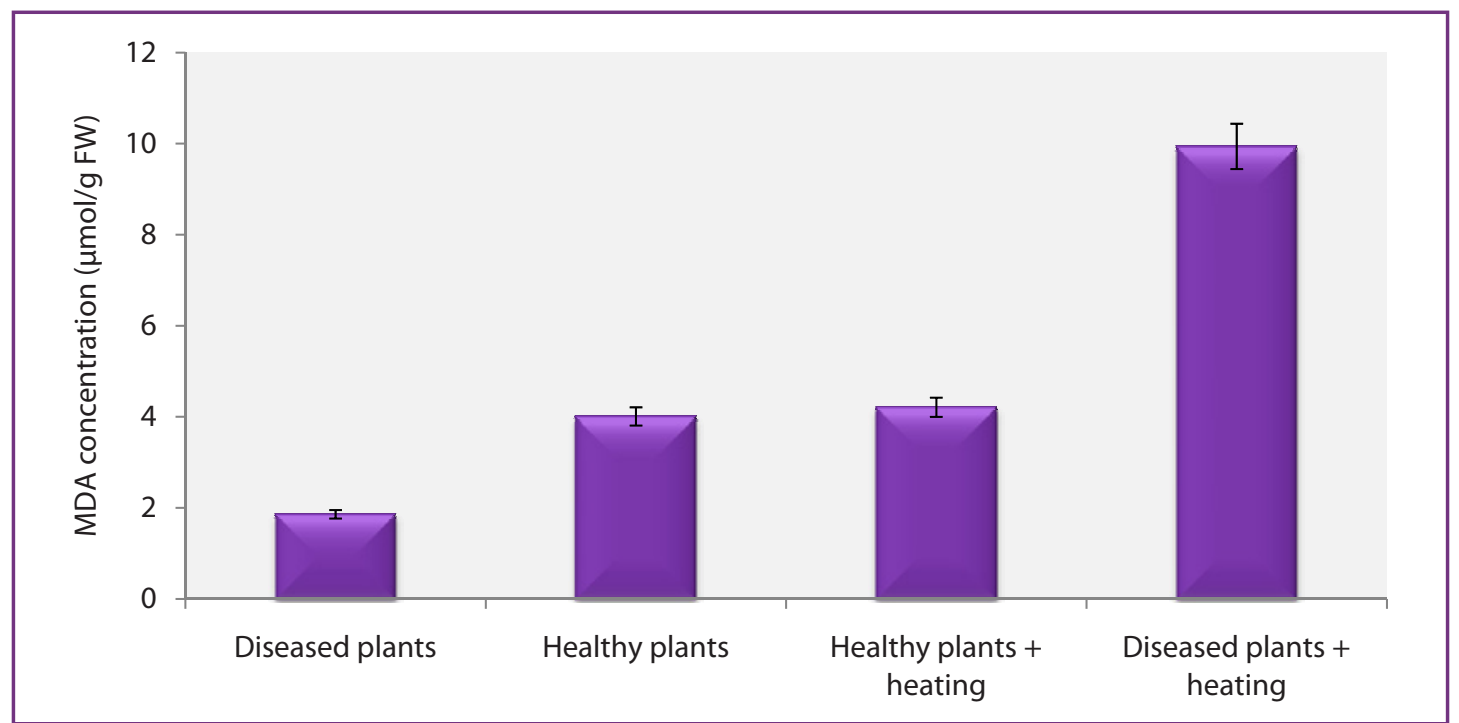

Figure 3 MDA content in Sambucus nigra L. plants when infected with viruses and under conditions of heat stress 
However, in infected leaves of elderberry, the content of malondialdehyde was significantly lower in optimal temperatures and was only $46 \%$ to healthy control. Under conditions of thermal stress, the content of MDA in diseased plants was increased by almost 5 times, compared to plants that were not exposed to thermal stress, and 2.3 times higher than in healthy plants exposed to increased temperatures. Thus, changes in the content of TBC-active products in the juice of infected elderberry plants indicate the activation of LP under conditions of temperature stress.

The results of our studies indicate the negative impact of viral infection on the antioxidant status of elderberry plants. Evidently, that the viral infection acts as an abiotic stress, in effects of which the protective reserves of the antioxidant system of the plant are exhausted. Future times, this state of elderberry plants will reduce the viability of plantings and early death of plants. In addition, under the conditions of double biotic and abiotic stress in plants, toxic products can accumulate which will reduce the nutritional quality of elderberry and will lead to deterioration of medicinal properties of substance from this plant. Further research on the ecology of viruses is needed, which infects the elderberry plants in Ukraine, to establish their transmission pathways in ecosystems and molecular biological studies to clarify the species' belonging to this group of viruses.

\section{Conclusions}

This is the first report about viral disease of elderberry plants of Sambucus nigra L. in Ukraine. The filamentous viral particles were detected in plants with symptoms of mosaic, chloratricity and ring spots. It was shown that under the conditions of viral infection, the activity of LP in the elderberry leaves is changing.

\section{References}

Atramentova, L., Utevskaya, O. 2008. Statistical methods in biology. Gorlovka : Lichtar. 248 p. ISBN 978-966-2129-26-7.

Cavileer, T., Halpern, B., Lawrence, D., Podleckis, E., Martin, R., Hillman, B. 1994. Nucleotide sequence of the carlavirus associated with blueberry scorch and similar diseases. Journal of General Virology, vol. 75, p. 711-720. Doi: 10.1099/0022-1317-75-4-711

Ding, M., Feng, R., Wang, S., Bowman, L., Lu, Y., Qian, Y., Castranova, V., Jiang, B., Shi, X. 2006. Cyanidin-3-glucoside, a natural product derived from blackberry, exhibits chemopreventive and chemotherapeutic activity. Journal of Biological Chemistry, vol. 281, p. 17359-17368. DOI: 10.1074/jbc.M600861200

Ebrahimzadeh, M., Enayatifard, R., Khalili, M., Ghaffarloo, M., Saeedi, M., Yazdani, C. 2014. Correlation between sun protection factor and antioxidant activity, phenol and flavonoid contents of some medicinal plants. Iranian Journal of Pharmaceutical Research, vol. 13, no. 3, p. 1041-1047. https://www. ncbi.nlm.nih.gov/pmc/articles/PMC4177626/

Ellis, P., Stace-Smith, R., Converse, R. 1992. Isolation and some properties of a North American carlavirus in Sambucus racemosa. Acta Hortic, vol. 308, p. 113-120. DOI: 10.17660/ActaHortic.1992.308.14

Gilmer, R., Kelts, L. 1968. Grape viruses and New York vineyards. N.Y. Food Life Sci, vol. 1, p. 3-5. http://www. apsnet.org/publications/phytopathology/backissues/Documents/1970Articles/Phyto60n04_619.pdf

Girbes, T., Ferreras, J., Arias, F., Stirpe, F. 2004. Description, distribution, activity and phylogenetic relationship of ribosome-inactivating proteins in plants, fungi and bacteria. Mini Reviews in Medicinal Chemistry. vol. 4, p. 461-476. DOI: 10.2174/1389557043403891

Gray, A., Abdel-Wahab, Y., Flatt, P. 2000. The traditional plant treatment, Sambucus nigra (elder), exhibits insulin-like and insulin-releasing actions in vitro. Journal of Nutrition, vol. 130, no. 1, p. 15-20. http:// jn.nutrition.org/content/130/1/15.full

Grbelja, J. 1972. Distribution of elders (Sambucus nigra L. and S. racemosa L.) infected with cherry leaf roll virus in Yugoslavia. Acta Bot. Croat, vol. 31, no. 1, p. 29- 36. hrcak.srce.hr/file/234904 
Hansen, A., Stace-Smith, R. 1971. Properties of a virus isolated from golden elderberry, Sambucus nigra aurea. Phytopathology, vol. 61, p. 1222-1229. DOI: 10.1094/Phyto-61-1222

Ho, T., Quito-Avila, D., Keller, K., Postmanc, J., Martinb, R., Tzanetakis, E. 2016. Evidence of sympatric speciation of elderberry carlaviruses. Virus Research, vol. 215, p. 72-75. DOI: 10.1016/j.virusres.2016.01.017.

Ho, T., Tzanetakis, I. 2014. Development of a virus detection and discovery pipeline using next generation sequencing. Virology, vol. 471, p. 54-60. DOI: 10.1016/j.virol.2014.09.019.

Horvath, J., Schmelzer, K., Kuretic, N. 1974. Isolation of cherry leaf roll virus from Sambucus nigra L. in Hungary. Acta Phytopathologica Academiae Scientiarum Hungaricae, vol. 9, no. 3/4, p. 209-218. https:// www.cabdirect.org/cabdirect/abstract/19751318597

Jiménez, P., Tejero, J., Cordoba-Diaz, D., Quinto, E., Garrosa, M., Gayoso, M., Girbés, T. 2015. Ebulin from dwarf elder (Sambucus ebulus L.): a mini-review. Toxins, vol. 7, no. 3, p. 648-658; DOI: 10.3390/toxins7030648

Jones, A. 1973. A comparison of some properties of four strains of cherry leaf-roll virus. Annals of Applied Biology, vol. 74, p. 211-217. DOI: 10.1111/j.1744-7348.1973.tb07740.x

Jones, A. 1972. Purification and properties of elderberry latent virus one of four obtained from American elder (Sambucus canadensis). Annals of Applied Biology, vol. 70, p. 49-58. http://onlinelibrary.wiley.com/ doi/10.1111/j.1744-7348.1972.tb04687.x/abstract

Jambunathan, N. 2010. Determination and Detection of Reactive Oxygen Species (ROS), Lipid Peroxidation, and Electrolyte Leakage in Plants. Sunkar, R. Plant Stress Tolerance: Methods and Protocols. Humana Press, Springer Science+Business Media, LLC, vol. 639, p. 291-301. DOI: 10.1007/978-1-60761-702-0_18

Kalinowska, E., Paduch-Cichal, E., Chodorska, M. 2013. First report of Blueberry scorch virus in elderberry in Poland. Plant Disease, vol. 97, p. 1515. http://dx.doi.org/10.1094/PDIS-03-13-0277-PDN

Keller, K., Mosier, N., Thomas, A. 2015. Identification of two new Carlaviruses in Elderberry. Acta Hortic, vol. 1061, p. 161-164. http://www.actahort.org/books/1061/1061_16.htm

Kiselova, Y., Ivanova, D., Chervenkov, T., Gerova, D., Galunska, B., Yankova, T. 2006. Correlation between the in vitro antioxidant activity and polyphenol content of aqueous extracts from bulgarian herbs. Phytother Res, vol. 20, p. 961-965. DOI: 10.1002/ptr.1985

Lapadula, W., Sánchez, P., Ayub, J. 2013. Revising the taxonomic distribution, origin and evolution of ribosome inactivating protein genes. PLoS One, vol. 8, e72825. DOI: 10.1371/journal.pone.0072825

Martin, G. 1925. Diseases of forest and shade tree, ornamental and miscellaneous plants in the united states in 1924. Plant Disease Reports, vol. 42, p. 313-380. https://archive.org/details/ diseasesofforest50mart.

Mishchenko, L., Taran, O., Glushchenko, L., Dunich, A. 2016. Detection of the pathogen of viral disease in Sambucus nigra plants. Bulletin of Taras Shevchenko National University of Kyiv. Series: Biology, vol. 72, no. 1, p. 78-80. http://biovestnik.com/index.php/biology

Pospieszny, H., Borodynko, N., Jończyk, M. 2004. First report of tomato black ring virus (TBRV) in the natural infection of Sambucus nigra in Poland. Journal of Plant Protection Research, vol. 44, p. 373-376. https:// www.yumpu.com/en/document/view/25380754/jppr-444vp-journal-of-plant-protection-research

Schmelzer, K. 1966. Untersuchungen an Viren der Zier und Wildgeholze. 5 Mitteilung: Virosen an Populus and Sambucus (Studies on viruses of ornamental and wild shrubs. 5. Viruses of Populus and Sambucus). Phytopathology. vol. 55, p. 317-351 http://onlinelibrary.wiley.com/doi/10.1111/j.1439-0434.1966. tb02236.x/abstract

Tejero, J., Jiménez, P., Quinto, E., Cordoba-Diaz, D., Garrosa, M., Cordoba-Diaz, M., Gayoso, M., Girbés, T. 2015. Elderberries: A Source of Ribosome-Inactivating Proteins with Lectin Activity. Molecules, vol. 20, no. 2, p. 2364-2387. DOI: 10.3390/molecules20022364

Van Lent, J., Wit, A., Dijkstra J. 1980. Characterization of a Carlavirus in Elderberry (Sambucus spp.). Neth. J. PI. Path., vol. 86, no 2, p. 117-134. DOI: 10.1007/BF01974340.

Way, R. 1981. Elderberry culture in New York state. New Yorks Food Life Sci. Bull. http://hdl.handle. net/1813/5098 